\title{
KEDUDUKAN HUKUM DARI WALI ANAK DI BAWAH UMUR DALAM MELAKUKAN TRANSAKSI PENJUALAN HARTA WARISAN
}

\author{
RUSFANDI \\ Dosen Fakultas Hukum Universitas Wiraraja Sumenep \\ rusfandi@gmail.com
}

\begin{abstract}
ABSTRAK
Setiap anak di bawah umur berada dalam kekuasaan orang tuanya. Orang tua dan anak mempunyai hubungan batiniah yang saling menghormati satu sama lain. Selain itu antara orang tua dan anak mempunyai hak dan kewajiban. Untuk menjamin terlaksananya hak dan kewajiban masing-masing pihak, maka Undang-undang mengaturnya. Akan tetapi tidak semua orang tua dapat menjalankan kewajibannya. Terdapat suatu keadaan dimana orang tua tidak dapat melaksanakan kewajibannya lagi, misalnya meninggalnya salah satu orang tua atau orang tua ada di dalam pengampuan atau sakit ingatan, dan lain-lain.
\end{abstract}

\section{KATA KUNCI : Kedudukan Hukum, wali Anak,Harta Warisan.}

\section{A. PENDAHUUAN}

Setiap anak di bawah umur berada dalam kekuasaan orang tuanya. Orang tua dan anak mempunyai hubungan batiniah yang saling menghormati satu sama lain. Selain itu antara orang tua dan anak mempunyai hak dan kewajiban. Untuk menjamin terlaksananya hak dan kewajiban masing-masing pihak, maka Undang-undang mengaturnya. Akan tetapi tidak semua orang tua dapat menjalankan kewajibannya.

Terdapat suatu keadaan dimana orang tua tidak dapat melaksanakan kewajibannya lagi, misalnya meninggalnya salah satu orang tua atau orang tua ada di dalam pengampuan atau sakit ingatan, dan lain-lain. Secara normatif memang orang tua itu sudah menjadi wali bagi anak kandungnya, dan bisa mewakili anaknya di luar dan di dalam pengadilan,hal seperti ini sesuai dengan Pasal 47 UndangUndang Nomor 1 Tahun 1974 tentang Perkawinan jo Pasal 98 Kompilasi Hukum
Islam. Pada umumnya dalam praktek di pengadilan, anak yang berumur di bawah sepuluh tahun, pengasuhannya atau perwaliannya diserahkan kepada ibunya, sedangkan bagi anak yang berumur di atas sepuluh tahun perwaliannya terserah kepada pilihan si anak sendiri, apakah dia akan ikut kepada ibunya ataukah memilih ikut pada bapaknya dalam hal perwalian bagi si anak. Apabila hal yang demikian ini terjadi maka putusan Pengadilanlah yang menentukan siapakah yang lebih berhak menjadi wali dari si anak tersebut.

Selain itu juga dalam Pasal 1 angka 10, Undang-Undang Nomor 35 Tahun 2014 tentang Perlindungan Anak terdapat pula istilah "Anak asuh" yaitu :"Anak yang diasuh oleh seseorang atau lembaga, untuk diberikan bimbingan, pemeliharaan, perawatan, pendidikan, dan kesehatan, karena orang tuanya atau salah satu orang tuanya tidak mampu menjamin tumbuh kembang anak 
secara wajar. Istilah kuasa asuh dan anak asuh ini setidak-tidaknya dapat memberikan gambaran mengenai pengertian dari hak asuh itu sendiri.

Jadi dalam suatu perkara perceraian, selain dapat memohonkan agar perkawinannya dinyatakan putus karena perceraian, maka salah satu pihak dapat memohonkan agar hak asuh atas anak-anak yang lahir dari perkawinan tersebut diberikan kepadanya. Masalah mengenai Perwalian ini, bagi Warga Negara Indonesia Asli berlaku hukum adatnya masing-masing seperti yang telah diatur dalam Stb.tahun 1931 Nomor 53. Bagi Warga Negara Indonesia keturunan Cina dan Keturunan Eropa, telah berlaku ketentuan Perwalian seperti yang tercantum dalam Kitab Undang-Undang Hukum Perdata. Ada beberapa faktor yang menentukan bagi hakim dalam memberikan putusan hak perwalian anak diantaranya adalah faktor usia anak dibawah umur, faktor kepentingan anak, faktor ekonomi wali dan faktor keberadaan anak.

Faktor-faktor tersebut selanjutnya Hakim akan mempertimbangkan masalah penetapan perwalian anak apakah perwalian anak jatuh ke tangan ayah atau ke tangan ibu. Dalam sebuah Pengadilan, Hakim memegang peranan penting sebagai pembuat keputusan, karena diharapkan putusan yang diberikan Hakim akan sesuai dengan hukum dan aturan yang berlaku sehingga keputusan yang diberikan diharapkan tidak akan berat sebelah, dalam hal penetapan perwalian anak diharapkan putusan yang diberikan Hakim akan menjamin masa depan dan kesejahteraan anak tersebut nantinya. Permasalahan lain yang dapat timbul dari pemberian hak asuh tersebut antara lain, keinginan dari pihak Bapak/ Ibu yang tidak mendapat hak asuh untuk tetap dapat bertemu dengan anakanaknya yang berada dalam pengasuhan Bapak/Ibu yang mendapatkan hak asuh atas anak-anak tersebut. Sehingga sekali lagi dapat dikatakan bahwa pemberian hak asuh kepada salah satu pihak, entah itu diberikan kepada pihak Bapak atau Ibu, sekali-kali tidak menghilangkan hubungan antara Bapak/Ibu yang tidak mempunyai hak asuh dengan anak tersebut.

Hal tersebut dapat dimohonkan agar dituangkan dalam putusan atas perkara tersebut (sesuai dengan permohonan para pihak) agar pihak Bapak/Ibu sewaktu-waktu dapat bertemu dengan anak-anaknya dengan sepengetahuan dari Bapak/Ibu yang mempunyai hak asuh atas anak tersebut. Selain itu dalam praktik juga terdapat permasalahan lain, apabila salah satu pihak sudah dinyatakan sebagai pemegang hak asuh, namun anak-anaknya berada dalam penguasaan pihak lain, dengan mengantongi putusan tersebut, apakah untuk mendapatkan anak tersebut perlu "dieksekusi" sebagaimana dalam perkara perdata lainnya. Sebaiknya tidak, karena anak bukanlah suatu barang melainkan pribadi yang mempunyai pikiran dan perasaan. Ada baiknya penyerahan atas anak tersebut dilakukan oleh suami dan isteri 
yang telah bercerai tersebut dengan cara mengkomunikasikannya terlebih dahulu secara baik-baik dan kekeluargaan, sehingga tidak menimbulkan permasalahan lain dikemudian hari, yang tentunya akan membawa efek negatif bagi perkembangan anak tersebut.

Berdasarkan ketentuan dalam Pasal 345 Kitab Undang-Undang Hukum Perdata, yaitu : "apabila salah satu dari kedua orang tua meninggal dunia, maka perwalian terhadap anak-anak yang belum dewasa demi hukum dipelihara oleh orang tua yang hidup terlama" Ketentuan tersebut dapat digugurkan dengan pemyataan dalarn Pasal 35 Undang-Undang No.35 tahun 2014, dengan alasan Lex Spesialis Derogat Lex Generalis dalarn Pasal 35 Undang-Undang No.35 tahun 2014 berbunyi : Salah satu orang tua, saudara kandung, atau keluarga sampai derajat ke 3 dapat mengajukan permohonan ke Pengadilan untuk mendapatkan penetapan pengadilan tentang pencabutan kuasa asuh orang tua atau melakukan tindakan pengawasan, apabila terdapat alasan yang kuat untuk itu. "Di dalam Undang-Undang No. 1 tahun 1974 mengenai masalah perwalian diatur dalam pasal 50-54.

Didalam pasal-pasal tersebut tidak sampai mengatur mengenai perwalian oleh perkumpulan, perwalian pengawas, pengampuan dan balai harta peninggalan seperti halnya di dalam Kitab UndangUndang Hukum Perdata, akan tetapi perwalian yang diatur disini adalah yang dilakukan orang perorangan dalam arti hukum lembaga khusus perwalian.Perwalian dapat dilihat dalam Pasal 50 ayat (1) UndangUndang No. 1 Tahun 1974 yang mengatakan bahwa anak yang belum mencapai umur 18 (depalan belas) tahun atau belum melangsungkan perkawinan, yang tidak berada di bawah kekuasaan orang tua, berada di bawah kekuasaan wal Pemilihan wali yang masih mempunyai hubungan keluarga ini dilakukan mengingat wali melakukan semua tugas, kewajiban dan kekuasaan orang tua yang meliputi juga penguasaan terhadap harta si anak. Diharapkan jika wali masih mempunyai hubungan keluarga maka kemungkinan terjadinya hal-hal yang tidak diinginkan terhadap penyelewengan pemakaian harta untuk keperluan pribadi oleh wali tidak akan terjadi.

Pada kenyatannya peneliti menemukan satu perkara yang keluar dari ketentuanketentuan tersebut di atas, dimana seorang ibu kandung memohon penetapan perwalian kepada Pengadilan Agama atas anak kandungnya, yang permohonan perwalian yang dilakukan oleh ibu atas anak kandungnya yang ayah kandung anak tersebut atau suami dari pemohon sudah meninggal dunia pada tahun 2007.

Pengajuan permohonan perwalian ini untuk dapat mewakili anaknya dalam melakukan perbutan hukum. Perbuatan hukum yang dimaksud adalah, pemohon bermaksud untuk menjual tanah waris bagian anaknya yang belum cukup umur untuk kebutuhan anaknya yaitu untuk kehidupan 
sehari - hari anaknya tersebut. Bentuk akhir dari permohonan ini adalah Majelis Hakim mengabulkan permohonan yang diajukan oleh pemohon.

\section{B. PEMBAHASAN}

Anak adalah generasi penerus bangsa dan penerus pembangunan, yaitu generasi yang dipersiapkan sebagai subjek pelaksanaan pembangunan yang berkelanjutan dan pemegang kendali masa depan suatu negara, tak terkecuali Indonesia. Berpedoman pada Pasal 1 butir 1 Undang-Undang Nomor 35 Tahun 2014 tentang Pelindungan Anak disebuntukan : "Anak adalah seseorang yang belum berusia 18 (delapan belas) tahun, termasuk anak yang masih di dalam kandungan.

Di dalam Undang-Undang No.3 Tahun 1997 tentang Pengadilan Anak, Terdapat definisi Anak, Anak Nakal, Anak Didik Pemasyarakatan. Yang dimaksud dengan Anak dalam Undang-Undang ini yaitu orang yang dalam perkara Anak Nakal telah mencapai umur 8 (delapan) tahun tetapi belum mencapai umur 18 (delapan belas) tahun dan belum pernah kawin. Anak Nakal adalah Anak yang melakukan perbuatan yang dinyatakan terlarang bagi Anak, baik menurut peraturan perundang-undangan maupun menurut peraturan Hukum lain yang hidup dan berlaku dalam masyarakat yang bersangkutan.

Sehubungan dengan hal kesejahteraan anak, dalam penjelasan umum Undangundang, dijelaskan bahwa oleh karena anak, baik secara rohani maupun jasmani, dan sosial belum memiliki kemampuan untuk berdiri sendiri, maka menjadi kewajiban bagi generasi terdahulu untuk menjamin, memelihara dan mengamankan kepentingan anak itu. Pemeliharaan, jaminan dan pengamanan ini selayaknya dilakukan oleh pihak yang mengasuhnya dibawah pengawasan dan bimbingan negara, bilamana perlu, oleh negara sendiri. Beberapa hak-hak anak dalam proses peradilan pidana perlu diberi perhatian khusus, demi peningkatan pengembangan perlakuan adil dan kesejahteraan yang bersangkutan. Selanjutnya hak-hak anak menurut Undang-undang No. 35 tahun 2014 tentang perubahan atas Undangundnag No.23 tahun 2002 tentang perlindungan anak yang terdapat dalam Pasal 4 (empat) sampai dengan Pasal 18 (delapan belas).

Pengertian anak menurut bahasa adalah turunan kedua, manusia yang masih kecil. Hukum perdata menjamin hak-hak dasar bagi seorang anak sejak lahir bahkan sejak masih dalam kandungan. Dalam hukum perdata, pengertian anak dimaksudkan pada pengertian "sebelum dewasa", karena menurut hukum perdata seorang anak yang belum dewasa sudah bisa mengurus kepentingankepentingan keperdataannya. Untuk memenuhi keperluan ini, maka diadakan peraturan tentang "handlichting", yaitu suatu pernyataan tentang seseorang yang belum mencapai usia dewasa sepenuhnya atau hanya 
untuk beberapa hal saja dipersamakan dengan seorang yang sudah dewasa.

Seorang anak yang belum dewasa senantiasa selalu dibawah pengawasan. Ini ditetapkan demikian oleh Undang-Undang untuk melindungi hak-hak mereka. Hukum kanak - kanak mempunyai sejarah yang sangat terkenal. Hukum anak bersifat sangat patriarchaal dimana anak-anak tidak mempunyai hak-hak. Anak-anak senantiasa ada dalam penguasaan bapak. Anak-anak merupakan paten porestas artinya anak sejak lahirnya sampai ia meninggal dunia merupakan milik orang tua berada di bawah kekuasaan ayah.

Menurut anggapan hukum pidana yang dipandang sebagai anak-anak ialah mereka yang berusia di bawah 16 tahun, sedangkan menurut hukum perdata, orang yang belum berumur 21 tahun termasuk anak - anak tetapi bila ia sudah menikah secara sah maka ia bukan lagi anak - anak atau jika ia memperoleh venia actatix.

Di dalam Pasal 299 BW, diatur bahwa kekuasaan orang tua hanya ada sepanjang perkawinan mereka masih berlangsung dan mereka tdak dibebaskan / dipecat dari kekauassan itu, Sedangkan dalam Pasal 300 : 1 ditetapkan bahwa yang menjalankan kekuasaan orang tua adalah bapak kecuali bapak dibebaskan /dipecat maka ibulan yang memegang kekuasaan orang tua (Pasal 300 : 2). Seandainya ibupun tidak bisa maka Pengadilan akan menentukan atau mengangkat seorang wali. Pasal 300 BW ini berbeda dgn Pasal 47:1 UU No. 1/1974, Dalam Pasal 47 ditetapkan bahwa "Anak yang belum mencapai umur 18 (delapan belas) tahun atau belum pernah melangsungkan perkawinan ada di bawah kekuasaan orang tuanya selama mereka tidak dicabut dari kekuasaannya." Dalam Pasal ini tidak ditentukan apakah bapak atau ibu yang lebih diutamakan dalam menjalankan kekuasaan orang tua.

Sebagai pengurus, orang tualah yang bertanggungjawab terhadap kekayaan anaknya yang berada berada dalam pengurusan. Kekuasaan orang tua adalah barang-barang yang dihibahkan kepada anaknya sendiri selama anak itu masih di bawah umur sedang harta/barang tertentu dari sang anak yang tidak berada dibawah pengurusan kekuasaan orang tua, yaitu barang harta yang diperoleh dari hibah /wasiat seseorang yang telah menentukan pelaksanaan pengurusan barang/harta tersebut. Apabila orang yang telah ditentukan tersebut berhalangan atau tidak bisa maka barulah orang tua yang mengurusnya. Ayah pengurus kekayaan dari anak-anaknya bertanggungjawab terhadap kekayaan tersebut.

Perwalian Menurut Asal Kata Perwalian (voogdij) berasal dari kata "wali" mempunyai arti orang lain selaku pengganti orang tua yang menurut hukum diwajibkan mengawasi dan mewakili anak yang belum dewasa atau belum akil-balig (berusia dibawah 18 tahun dan belum menikah). Sehingga perwalian 
dapat diartikan sebagai orang tua pengganti terhadap anak yang belum cakap dalam melakukan suatu perbuatan hukum. Kata wali dalam bahasa Arab berasal dari kata-kata wilayah (kata benda) kata kerjanya walia yang artinya berkuasa.

Di dalam peraturan perundang-undangan, perwalian diatur dalam Undang-Undang Nomor 1 tahun 1974 tentang Perkawinan : Pertama: Pasal 50 ayat (1) yang menyatakan bahwa anak yang belum mencapai umur 18 (delapan belas) tahun atau belum pernah melangsungkan perkawinan yang tidak berada di bawah kekuasaan orang tua, berada di kekuasaan wali. Perwalian tersebut juga mengenai pribadi anak yang bersangkutan maupun harta bendanya..

Perwalian tidak lain merupakan suatu perbuatan hukum yang melahirkan akibat hukum berupa hak dan kewajiban sehingga dalam pelaksanaannya dituntut harus sesuai dengan aturan-aturan hukum yang berlaku. Sering orang berbicara atau bahkan melakukan atau mengemban tugas dan kewajiban sebagai wali tetapi tidak pernah tahu secara tepat di mana masalah perwalian itu diatur dan bagaimana perwalian itu harus dilaksanakan sesuai dengan ketentuan hukum yang berlaku. Sehingga terjadilah tindakantindakan yang justru menyimpang dari tujuan sesungguhnya lembaga perwalian. Padahal, aturan hukum mengenai perwalian telah lama ada sebagaimana tercantum dalam beberapa peraturan perundang-undangan yang berlaku.
Asas-asas Perwalian asas tidak dapat dibagi bagi dan asas persetujuan dari keluarga.

Kewenangan perhimpunan-perhimpunan, yayasan-yayasan dan lembaga amal sebagai wali apabila diperintahkan oleh Pengadilan. Sebab, badan hukum tidak dapat diangkat menjadi wali apabila perhimpunanperhimpunan, yayasan dan lembaga amal sebagai wali adalah berdasarkan ditunjuk oleh orang tua.

Di dalam Pasal 365 Kitab UndangUndang Hukum Perdata menjelaskan bahwa dalam hal sebuah badan hukum diserahkan perwalian, maka Panitera Pengadilan yang menugaskan perwalian tersebut wajib memberitahukan putusan Pengadilan itu kepada Dewan Perwalian dan Kejaksaan.

Istilah pengampuan dalam bahasa hukum berasal dari bahasa Belanda yakni curatele yang dalam bahasa Inggris disebut dengan kata custody dan interdiction dalam bahasa Perancis. Kata pengampuan dalam bahasa Indonesia merupakan kata yang terbentuk dari kata dasar "ampu" yang mendapat imbuhan (tambahan) awalan "pe" dan akhiran "an". Kata "ampu" memiliki arti orang yang menjaga keselamatan orang lain; wali, orang tua, pembimbing. Sedangkan pengampuan adalah perwalian terhadap seseorang yang telah dewasa yang disebabkan karena gila, terlalu boros, dungu.

Istilah dan praktek pengampuan juga dikenal dalam Islam yang disebut dengan istilah al hajr. Secara bahasa kata al hajru 
berasal dari hajaru-yahjuru-hajron, yang mempunyai beberapa arti, diantaranya melarang, mengharamkan, mengeras dan ruangan. Dari dua pengertian tersebut dapat disimpulkan bahwa al hajru merupakan suatu tindakan preventif dalam hal tasharruf baik yang terkait dengan ucapan (akad) dan harta benda

Dasar pengampuan bisa dilihat dari dua sudut pandang hukum, yaitu dari hukum Islam dan hukum positif. Dasar hukum pengampuan dalam hukum Islam dapat disandarkan pada beberapa dalil.

Dalam hukum positif di indonesia, pengampuan diatur dalam KUH Perdata dalam buku kesatu tentang orang dalam bab XVII yang membahas tentang pengampuan. Dasar hukum yang terkait legalitas pengampuan tersebut disebuntukan dalam Pasal 433 berikut: "Setiap orang dewasa, yang selalu berada dalam keadaan dungu, sakit otak atau mata gelap harus ditaruh dibawah pengampuan, pun jika ia kadangkadang cakap mempergunakan pikirannya. Seorang dewasa boleh juga ditaruh dibawah pengampuan karena keborosannya

Pengampuan pada dasarnya terjadi karena adanya ketidakcakapan seseorang dalam mengelola harta kekayaannya. Memang secara umum dapat disimpulkan seperti itu, akan tetapi lebih detailnya sebab dari pengampuan dalam perspektif hukum Islam adalah sebagai berikut:Anak kecil,Gila,Pemboros,Pailit/bankrut ，Sakit berat, Hamba yang tidak diberi ijin bertransaksi

Apabila wali anak itu orang kaya, dia tidak boleh mengambil nafkahnya dari harta anak itu. Sekiranya tidak punya maka dapat mengambil sekedarnya untuk menutupi keperluan sehari-hari. Sedangkan untuk menilai anak itu apakah ia sudah cerdas atau belum, menurut jumhur ulama, harus senantiasa diuji dalammembelanjakan hartanya. Apabila ia telah terampil mengelola harta sendiri, dalam artian tidak merugikan dirinya lagi, maka ia dianggap cerdas.

Apabila anak itu belum memenuhi kedua syarat diatas, maka wali anak itu tidak boleh menyerahkan harata itu kepada anak itu dan yang bertindak sebagai pengelola dan pemelihara harta itu adalah walinya, dan pengelolaan terhadap harta itu harus senantiasa bertitik tolak pada kemaslahatan anak itu. Akan tetapi, bila wali itu orang miskin, para ulama fiqh sepakat menyatakan bahwa wali boleh mengambil nafkahnya

Berlakunya seseorang sebagai pembawa hak adalah dimulai sejak ia dilahirkan dan berakhir pada saat ia meninggal. Pengampuan berakhir jika sebab-sebab pengampuan sudah hilang. Tentang hubungan hukum antara kuradus dan kurator. Tentang syarat-syarat timbul dan hilangnya pengampuan dan sebagainya diatur dalam peraturan tentang pengampuan.

Berbicara masalah perwalian atas seorang anak maka tidak telepas dari pembahasan anak dan batas usia seorang 
anak, ini penting karena untuk mengetahui bilamana seorang anak diletakkan dibawah perwalian dan dapat mempertangung jawabkan suatu perbuatanya. Anak dalam bahasa arab disebut walad, satu kata yang mengandung penghormatan, sebagai makhluk ciptaan tuhan yang sedang menempuh perkembangannya kearah abdi allah yang saleh, dimana dengan memandang anak dan kaitannya dengan perkembangan membawa arti bahwa anak diberikan tempat khusus yang berbeda dengan kehidupan orang dewasa, dan anak memerlukan perhatian dan perlakuan khusus dari orang dewasa dan para pendidiknya, artinya kehidupan anak tidak dipenggal dan dilepaskan dari dunianya serta dimensi dan prospeknya." Penempatan wali ini sangat penting, terlebih pada masalah pewarisan. Apabila orang tua sianak yang belum dewasa meninggal dunia maka sianak tersebut akan mendapatkan harta warisan dari orang tuannya itu maka si anak harus diwakilkan oleh walinya, sehingga dengan akibat tersebut harta peninggalan yang didapatkan seorang anak atas peristiwa peninggalannya kedua orang tuanya dapat memenuhi rasa keadilan dan kepastian hukum.

Setiap ada kematian, yang harus dilakukan adalah membuatSurat Keterangan Waris-nya ("SKW"). Dari surat tersebut diketahui siapa saja ahli waris yang berhak mewaris, termasuk dapat diketahui apakah ahli waris tersebut sudah dewasa (dapat melakukan perbuatan hukum sendiri) atau belum. Seseorang yang sudah dewasa atau sudah menikah secara hukum di istilahkan sebagai: "cakap menurut hukum". Dan terhadap ahli waris yang belum cakap untuk melakukan perbuatan hukum, diperlukan izinizin khusus dari pihak yang berwenang. Mengenai SKW, Saudara dapat juga membaca artikel Keterangan Warisdan Perbedaan Surat Keterangan Waris dengan Akta Keterangan Hak Mewaris.

\section{PENUTUP}

Pertimbangan Hukum Bagi Anak Dibawah Umur Dalam Melakukan Transaksi Jual Beli Harta Warisan, hukum perdata menjamin hak-hak dasar bagi seorang anak sejak lahir bahkan sejak masih dalam kandungan. Secara otomatis, anak yang dibawah umur dalam kedudukannya menjual harta waris secara normatif bisa perwalian yang menjadi pengasuh bagi anaknya, dan secara normatif diperlukan adanya perizinan penjualan harta warisan. Tanggung jawab wali atas pengurusan harta anak dibawah umur menurut ketentuan hukum, dimana wali bertindak sama seperti orang tua bagi anak yang masih dibawah umur sewaktu menjalankan kekuasaan wali, dengan adanya hak perwalian ini meberikan suatu gambaran bahwa setiap manusia tidak dapat melaksanakan haknya secara individual.

Kedudukan Hukum Wali Dari Anak Dibawah Umur Dalam Melakukan Transaksi Penjualan Harta Warisan Pasal 47 Undang Undang Nomor 1 Tahun 1974 
jo pasal 98 mengatakan orang tua berhak untuk menjadi mewakili anaknya diluar ataupun di dalam Pengadilan. Tapi pada kenyataannya orang tua yang ingin mewakilkan anaknya dalam melakukan tindakan hukum harus ada penetapan perwalian dari Pengadilan. Selain itu dalam melakukan tindakan hukum dibutuhkan suatu bukti yang jelas atau legalitas. Bentuk perlindungan hukum yang diberikan terhadap harta anak dibawah umur yang berada dibawah pengurusan wali berupa pengawasan atas pengelolaan barang-barang dari anak yang belum dewasa. Pada awal penetapan perwalian, diperlukan upaya inventarisasi semua harta dari anak dibawah umur tersebut, dan wali wajib mendokumentasikan semua perubahan terhadap asset tersebut. Harta tersebut harus diaudit secara tahunan untuk mengetahui nilai dari aset dari anak yang di bawah perwalian, dan untuk memastikan bahwa hartanya tetap terjaga. Selain itu, wali dilarang menjual, mengalihkan atau menggadaikan aset anak perwalian, kecuali dalam keadaan yang darurat. Wali juga dilarang mengikat, membebani atau membagi harta tersebut kecuali tindakan tersebut akan meningkatkan atau menambah nilai harta, jika dalam hal wali terpaksa menjual harta milik anak perwalian tersebut, maka seorang wali wajib terlebih dahulu memperoleh izin dari pengadilan agama.

\section{DAFTAR BACAAN}

Abdurrahman dan Riduan Syahrani, 2008, Hukum Perkawinan, Alumni Bandung.

Burhan Bungin, 2009, Metodologi Penelitian Kualitatif ; Aktualisasi Metodologis ke Arh Ragam Varian Kontemporer, PT. Raja Grafindo Persada, Jakarta.

Hasbullah Bakry, 2008, Pedoman Islam di Indonesia, UI-Press, Jakarta.

Kamus Besar Bahasa Indonesia. cet.2. Jakarta: Balai Puataka. 2010.

Masri Singarimbun dan Sofian Effendi, 2009, Metode Penelitiaan Survei, LP3ES, Jakarta.

Marwan dan Jimmy P, 2009, Kamus Hukum, Reality Publiser, Surabaya.

Nashriana, 2011, Perlindungan Hukum Pidana Bagi Anak di Indonesia, Raja Grafindo Persada, Jakarta.

Titik Triwulan, 2008, Hukum Perdata dalam Sistem Hukum Nasional, Prenada Media Group, Jakarta.

Kitab Undang-Undang Hukum Perdata;

Undang-Undang Nomor 1 Tahun 1974tentang Perkawinan;

Undang-Undang Nomor 4 Tahun 1979 tentang Kesejahteraan Anak;

Undang-Undang Nomor 3 Tahun 1997 tentang Pengadilan Anak;

Undang-Undang Nomor 11 Tahun 2012 tentang Sistem Peradilan Pidana Anak.

Undang-Undang Nomor 35 Tahun 2014 tentang Perlindungan Anak. 